\title{
Defense mechanisms of Solanum tuberosum L. in response to attack by plant-pathogenic bacteria
}

\author{
VERA A D. POIATTI, FERNANDO R DALMAS and LEANDRO V ASTARITA
}

Laboratório de Biotecnologia Vegetal, Departamento de Biologia Celular e Molecular, Faculdade de Biociências, Pontifícia Universidade Católica do Rio Grande do Sul (PUCRS). Porto Alegre, RS, Brazil

\begin{abstract}
The natural resistance of plants to disease is based not only on preformed mechanisms, but also on induced mechanisms. The defense mechanisms present in resistant plants may also be found in susceptible ones. This study attempted to analyze the metabolic alterations in plants of the potato Solanum tuberosum L. cv. Agata that were inoculated with the incompatible plant-pathogenic bacteria $X$. axonopodis and $R$. solanacearum, and the compatible bacterium E. carotovora. Levels of total phenolic compounds, including the flavonoid group, and the activities of polyphenol oxidase (PPO) and peroxidase (POX) were evaluated. Bacteria compatibility was evaluated by means of infiltration of tubers. The defense response was evaluated in the leaves of the potato plants. Leaves were inoculated depending on their number and location on the stem. Multiple-leaf inoculation was carried out on basal, intermediate, and apical leaves, and single inoculations on intermediate leaves. Leaves inoculated with $X$. axonopodis and with $R$. solanacearum showed hypersensitive responses within 24 hours post-inoculation, whereas leaves inoculated with $E$. carotovora showed disease symptoms. Therefore, the $R$. solanacearum isolate used in the experiments did not exhibit virulence to this potato cultivar. Regardless of the bacterial treatments, the basal leaves showed higher PPO and POX activities and lower levels of total phenolic compounds and flavonoids, compared to the apical leaves. However, basal and intermediate leaves inoculated with $R$. solanacearum and X. axonopodis showed increases in total phenolic compounds and flavonoid levels. In general, multiple-leaf inoculation showed the highest levels of total phenolics and flavonoids, whereas the single inoculations resulted in the highest increase in PPO activity. The POX activity showed no significant difference between single- and multiple-leaf inoculations. Plants inoculated with E. carotovora showed no significant increase in defense mechanisms such as enzyme activity and phenolic compounds. Therefore, resistance or susceptibility in S. tuberosum cv. Agata might depend on leaf age, type of inoculation performed (single or multiple), and the interaction between plant and pathogen.
\end{abstract}

Key terms: flavonoids, hypersensitive response, peroxidases, phenolic compounds, polyphenol oxidases.

\section{INTRODUCTION}

The potato (Solanum tuberosum L.), the fourth most important commercial crop in the world, can be affected by many biotic and abiotic factors, including pathogens and environmental stresses (Juskiewicz et al., 2005; Rauscher et al., 2006). This is a serious economic problem in countries where potatoes are cultivated over large areas. Among the potato cultivars, Agata is the most promising because of the uniformity and good features of its tubers. Furthermore, it produces many stems and tubers per plant, which contributes to its status as the best-producing variety in Brazil (Pineli et al., 2006). In spite of its importance, the Agata cultivar is very sensitive to most potato diseases. Some of the important diseases are the bacterial wilt caused by Ralstonia solanacearum, the bacterial soft rot caused by Erwinia carotovora, and the late blight and the early blight caused by the fungi Phytophthora infestans and Alternaria solani, respectively (Nasareno and Jaccoud Filho, 2003; Oliveira et al., 2003). 
The natural resistance of plants to diseases is based not only on preformed defenses, but also on induced mechanisms.

The induced mechanisms are associated with local changes at the site of pathogen infection, such as the hypersensitive response (HR), which is one of the most efficient forms of plant defenses (Kortekamp and Zyprian, 2003). In addition to causing accumulation of antimicrobial compounds, such as phenolic compounds and phytoalexins (Ortega et al., 2005), the HR also leads to an increase in the activity of peroxidases (Kortekamp and Zyprian, 2003) and polyphenol oxidases enzymes (Agrios, 1997) involved in defense responses (Thipyapong et al., 2004).

Phenolic compounds, namely pterocarpans, coumarins, flavonols, and isoflavones (Dixon and Paiva, 1995; Harbone, 1999), are an important group of secondary metabolites involved in resistance to pathogens due to their antimicrobial activity. The HR response and accumulation of phenolic compounds, such as antimicrobial phytoalexins, were well documented in tobacco plants inoculated with tobamovirus coat protein (Ehrenfeld et al., 2005). Phenylpropanoid compounds have been shown to be essential to resistance to Cochliobolus heterostrophus and Peronospora sorghi in maize and sorghum plants, respectively (Nicholson and Hammerschmidt, 1992; Anwar, 1995). The resistance of Arabidopsis leaves to attack by pathogens is related to the presence of the aromatic compound camalexin (Bednarek et al., 2005). Similarly, catechin synthesis in strawberry leaves is able to inhibit penetration of hyphae of Alternaria alternata (Yamamoto et al., 2000). Flavonoids are the largest class of phenolics, and show antimicrobial and antioxidant properties (Lorenc-Kukula et al., 2005). Tubers, flowers, and leaves of potato plants produce flavanones, flavonols, and flavan-3-ols (Lewis et al., 1998). Isoflavans, isoflavanones, prenylated isoflavonoids, coumarins, 3-deoxyantocyanidins, and flavonols are the best-characterized phenylpropanoid-derived phytoalexins (Dixon and Paiva, 1995; Dixon et al., 2002). The phytoalexins 3-deoxyanthocyanidin in Sorghum sp. (Field et al., 2006), sakuranetin and naringenin in Oryza sativa L. (Jwa et al., 2006), and glyceollins in Glycine $\max$ (L.) Merrill. (Abbasi and Graham, 2001) are produced after a pathogen attack.

Polyphenol oxidase enzymes (PPOs) (EC 1.14.18.1 or EC 1.10.3.2) are widely distributed within the plant, and act in the defense responses (Thipyapong et al., 2004). The induction of a PPO isoform in tomatoes susceptible to Pseudomonas syringae pv. tomato and Alternaria solani suggests that this enzyme plays a role in disease resistance (Thipyapong and Steffens, 1997). The overexpression of PPO in tomato leads to a significant increase in resistance to $P$. syringae pv. tomato in compatible interactions ( $\mathrm{Li}$ and Steffens, 2002). PPO activity is induced in chickpea leaves (Cicer arietinum L.) after inoculation with Ascochyta rabei (Khirbat and Jalali, 1998). PPOs act in disease resistance by hydroxylizing monophenols to $o$-diphenols and oxidizing these compounds to quinones, which are often more toxic to the microorganisms than the original phenolic compounds (Gandia-Herrero et al., 2005). Peroxidase enzymes (POX, EC 1.11.1.7) are also related to plant defense, acting in strengthening the cell wall (Agrios, 1997; De Ascensão and Dubery, 2003); and some studies have demonstrated their interference with the growth and development of the pathogen in cucumbers and cotton (Nicholson and Hammerschmidt, 1992; Dellanoy et al., 2004). In addition, PPO and POX are multifunctional enzymes that can prevent biological and chemical attacks by raising physical barriers or by counterattacking a pathogen with a high production of free radicals (Passardi et al., 2005). In resistant varieties of grapevine, there is not only a higher basal activity of these enzymes, but also a rapid increase in their activity after pathogen inoculation (Kortekamp and Zyprian, 2003).

The aim of this study was evaluate the defense mechanisms of Solanum tuberosum $\mathrm{cv}$. Agata in response to plant bacterial pathogens, by analyzing the occurrence of the hypersensitive response, changes in the levels of total phenolic compounds and flavonoids, and the activities of the polyphenol oxidases and peroxidases. 


\section{MATERIALS AND METHODS}

\subsection{Plant material}

Seed tubers of Solanum tuberosum cv. Agata were provided by potato growers (São Francisco de Paula, RS, Brazil, 2926'49'S 50³4'44”W). In greenhouse, tubers were sown and plants were grown in pots with commercial organic soil. Seven to ten-week-old plants exhibiting 12-14 leaves were used for the experiments. Leaves were numbered according to their time of appearance. Leaves located at the base of the stem were numbered from 1 to 4 , intermediate leaves were numbered from 5 to 8 and apical leaves were numbered from 9 to 12 .

\subsection{Plant pathogens}

Cultures of phytobacteria were provided by Dr. Valmir Duarte (Laboratory of Phytopathology, Universidade Federal do Rio Grande do Sul, Brazil). Xanthomonas axonopodis pv. citri, Erwinia carotovora subsp. carotovora and Ralstonia solanacearum race 1 (biovar 1) were grown in liquid LB medium (10 g . $\mathrm{L}^{-1}$ tryptone, 5 $\mathrm{g} . \mathrm{L}^{-1}$ yeast extract, $\left.10 \mathrm{~g} . \mathrm{L}^{-1} \mathrm{NaCl}\right)$ at $28{ }^{\circ} \mathrm{C}$ for $48 \mathrm{~h}$ under $100 \mathrm{rpm}$. Cultures were centrifuged at $1,250 \mathrm{~g}$ for $10 \mathrm{~min}$ at $10{ }^{\circ} \mathrm{C}$. The supernatants were discarded and the pellets were re-suspended in $3 \mathrm{~mL}$ of sterile distilled water. The bacteria were washed three times. In the final step, the pellet was re-suspended in $3 \mathrm{~mL}$ of sterile distilled water and the bacterial concentration was adjusted to $10^{8}-10^{9} \mathrm{cfu} \cdot \mathrm{mL}^{-1}\left(\mathrm{OD}_{600 \mathrm{~nm}}=\right.$ 0.3-0.4) (Romeiro, 2001). The suspensions were immediately used for inoculation of potato leaves and tubers.

\subsection{Tuber infection}

Tubers were infected in order to evaluate the bacterial compatibility/incompatibility. Potato tubers were washed throughly in tap water, immersed in a sodium hypochloride solution ( $0.5 \%$ active chloro) for $15 \mathrm{~min}$ and rinsed three times in sterile water. Aliquots of bacterial suspensions were inoculated into the tuber's parenchyma $(5 \mathrm{~mm}$ in depth) using sterile toothpicks. Three series of five tubers were used for each species of bacteria. The control consisted of tubers infiltrated with sterile distilled water. Inoculated tubers were incubated in sterile Magenta boxes at $25{ }^{\circ} \mathrm{C}$. They were then sliced along the longest lenght 48 hours and 30 days post- inoculations and visible defense reactions or disease symptoms were analyzed.

\subsection{Leaf infection}

Experiments consisted of multiple and single inoculations, which were performed depending on the number of leaves and their location on the stems. Multiple inoculation in each plant consisted of inoculation of bacterial suspensions in four leaves located at each basal, intermediate and apical position of the stems. Single inoculation consisted of inoculation in four leaves located at the intermediate position of the stems.

About 20-25 $\mu \mathrm{L}$ of the bacterial suspensions were inoculated on the lamina tissues of potato leaves by gentle pressure infiltration through the stomata of the abaxial surface by using a syringe without needle. Suspensions were inoculated on the middle portion of the terminal leaflets, between veins. Plants infiltrated with sterile distilled water were used as control. In all experiments, before and after infiltration, plants were incubated for $48 \mathrm{~h}$ at room temperature and high relative humidity (80\%) (Romeiro, 2001). The experiments of multiple and single inoculations were carried out with three and nine plants, respectively. Defense reactions were evaluated in leaves 48 and 96 hours postinoculation (hpi) from the experiments of single and multiple inoculations. Samples included the inoculated area and the surrounding mesophyll.

\subsection{Enzyme activities}

Leaf samples $(0.5 \mathrm{~g})$ were ground in $5 \mathrm{~mL}$ of $50 \mathrm{mM}$ sodium phosphate buffer $(\mathrm{pH}$ $7.0)$, containing $1 \%$ Triton $X-100(\mathrm{v} / \mathrm{v})$ and polyvinylpolypyrrolidone (PVPP) (1: $6 \mathrm{w} /$ v). Extracts were filtered and centrifuged 
at $2,500 \mathrm{~g}$ for $15 \mathrm{~min}$ at $5{ }^{\circ} \mathrm{C}$, and the supernatants were used for enzyme assays. Polyphenol oxidase activity was determined spectrophotometrically at 400 nm using chlorogenic acid as substrate. The enzyme activity unit was defined as the change in absorbance $. \min ^{-1} . \mu \mathrm{g}^{-1}$ protein (González et al., 1999). Peroxidase activity was determined spectrophotometrically by the oxidation of guaiacol at $420 \mathrm{~nm}$, using the extract described above. The reaction mixture contained $50 \mathrm{mM}$ sodium phosphate buffer $(\mathrm{pH} 6.0), 0.1 \mathrm{M}$ guaiacol as substrate and $10 \mathrm{mM}$ hydrogen peroxide. The enzyme activity unit was expressed in mkatal .min ${ }^{-}$ ${ }^{1} . \mu g^{-1}$ protein. One katal (kat) corresponds to the quantity of enzyme activity that transforms $1 \mathrm{~mol} . \mathrm{s}^{-1}$ of substrate (Randhir et al., 2002). Protein was determined according to Bradford (1976), with bovine serum albumin as standard.

\subsection{Phenolic compounds and flavonoids}

Leaf samples $(0.5 \mathrm{~g})$ were ground in $10 \mathrm{~mL}$ of $80 \%$ methanol $(1: 20 \mathrm{w} / \mathrm{v})$. Extracts were filtered and centrifuged at $1,250 \mathrm{~g}$ for $15 \mathrm{~min}$ at $15{ }^{\circ} \mathrm{C}$. Phenolic compounds were quantified by the colorimetric technique using Folin-Ciocaulteau reagents and $\mathrm{Na}_{2} \mathrm{CO}_{3}(20 \% \mathrm{w} / \mathrm{v})$. Absorbancy (765 nm) was determined after $30 \mathrm{~min}$ incubation at $25{ }^{\circ} \mathrm{C}$ in the dark (Arnaldos et al., 2001). Gallic acid was used as standard. Levels of the flavonoids were determined spectrophotometrically at $415 \mathrm{~nm}$, using the reaction with $96 \%$ alcohol, $10 \%$ aluminum nitrate and $1 \mathrm{M}$ potassium acetate. Flavonoid content was expressed as $\mathrm{mg}$ quercetin equivalents/g FW (Toor and Savage, 2005).

\subsection{Chlorophyll levels in leaves}

Leaves $(0.2 \mathrm{~g})$ were ground in $20 \mathrm{~mL} 80 \%$ acetone (1: $100 \mathrm{w} / \mathrm{v}$ ) and $100 \mathrm{mg} \mathrm{CaCO}_{3}$. Extracts were used to determine the level of chlorophyll $a$, chlorophyll $b$ and total chlorophyll in spectrophotometer at 663, 645 and $652 \mathrm{~nm}$, respectively. Concentrations were calculated as described by Whitham et al. (1971).

\subsection{Statistics}

Mean values are shown for phenolics, flavonoids, chlorophyll contents and enzyme activities. Data were analyzed using one-way ANOVA and multivariate general linear model procedures.

Means were separated by Tukey posthoc test, with the significance level of $\mathrm{p} \leq$ 0.05 (software SPSS version 11.5). When necessary, data were transformed by $\sqrt{ } \mathrm{x}+0.5$, in order to obtain homogeneity of variance.

\section{RESULTS}

\subsection{Compatible and incompatible plant responses}

Tubers infiltrated with E. carotovora exhibited visible disease symptoms up to 48 hpi (hour post-inoculation). The disease spread rapidly, and was characterized by darkness and soft rot, indicating the susceptibility of the Agata cultivar. Tubers inoculated with $R$. solanacearum did not develop disease symptoms, but brown spots were visible, indicating the occurrence of cell death. In contrast, neither a hypersensitive response (HR) signal nor disease symptoms were observed in the tubers inoculated with $X$. axonopodis. Likewise, control treatments did not result in any defense signals after the inoculations (data not shown).

When leaves were inoculated with $X$. axonopodis and $R$. solanacearum, a HR could be seen at $24 \mathrm{hpi}$, while leaves inoculated with E. carotovora showed disease symptoms (data not shown).

\subsection{Multiple inoculations (basal, intermediate, and apical leaves)}

Regardless of leaf age, PPO activity was characterized by significant differences between treatments (Table I). When $R$. solanacearum and $E$. carotovora were inoculated into potato leaves, a significant increase in PPO activity was observed at 96 hpi. Similarly, an increase in POX activity was detected after $R$. solanacearum 
infection (96 hpi) (Table I). Surprisingly, the infiltration of leaves with water (control treatment) also caused changes in the PPO activity.

Bacteria inoculation resulted in changes in the secondary compounds. There was a significant increase in the levels of phenolic compounds in the leaves inoculated with both $X$. axonopodis and $R$. solanacearum, while the highest flavonoid levels were found after infection with $R$. solanacearum (Fig. 1 A, B). These responses were easily observed at 96 hpi with both bacteria, independently of the age of the leaf. Leaves inoculated with E. carotovora contained the lowest levels of phenolic compounds, with no significant difference from the levels found in intact leaves (Fig. $1 \mathrm{~A}$ ).

When leaf age was considered, potato plants inoculated with the bacteria $X$. axonopodis and $R$. solanacearum showed similar responses (Table II), in which the apical (youngest) leaves showed significantly higher levels of phenolic compounds than the basal leaves. Similarly, the highest increase of flavonoids was observed in the apical leaves of plants inoculated with $R$. solanacearum (Table II). In contrast, the most significant increase of
PPO and POX activity was found in the basal leaves of plants inoculated with $E$. carotovora and $R$. solanacearum, respectively (Table II). Untreated basal leaves (Table III) showed lower levels of phenolic compounds and flavonoids, higher levels of PPO and POX activity, and lower contents of chlorophyll and soluble proteins than the apical leaves.

\subsection{Single inoculation (intermediate leaves)}

Single inoculations in intermediate leaves led to a significant increase in PPO activity when the leaves were inoculated with $R$. solanacearum (96 hpi) and $X$. axonopodis (48 and $96 \mathrm{hpi}$ ), as well as an increase in POX activity with E. carotovora (48 hpi) (Table I).

The increase in the levels of total phenolic compounds and flavonoids was less significant than those observed with multiple inoculations. The highest level of phenolic compounds was observed in leaves inoculated with $E$. carotovora. A similar increase occurred in the flavonoid levels, when leaves were inoculated with $X$. axonopodis (48 and 96 hpi) (Fig. 1 C, D).

TABLE I

Activity of polyphenol oxidases (PPO) and peroxidases (POX) in leaves of Solanum tuberosum analyzed -after multiple and single inoculations. Assays of PPO and POX activities were performed 48 hpi and 96 hpi (hours post-inoculation).

\begin{tabular}{|c|c|c|c|c|c|}
\hline \multirow[b]{2}{*}{ Treatments } & \multirow[b]{2}{*}{ hpi } & \multicolumn{2}{|c|}{ Multiple } & \multicolumn{2}{|c|}{ Single } \\
\hline & & $\begin{array}{c}\mathrm{PPO} \\
\left(\Delta A b \text { s.min }{ }^{-1} \cdot \mu g^{-1}\right. \\
\text { protein })\end{array}$ & $\begin{array}{c}\text { POX } \\
\text { (mkatal } \mu g^{-1} \\
\text { protein) }\end{array}$ & $\begin{array}{c}\mathrm{PPO} \\
\left(\Delta A b s . \text { min }^{-1} \cdot \mu g^{-1}\right. \\
\text { protein })\end{array}$ & $\begin{array}{c}\text { POX } \\
\text { (mkatal } \mu g^{-1} \\
\text { protein) }\end{array}$ \\
\hline \multirow[t]{2}{*}{ Intact leaves } & 48 & $19.59(3.53)^{\mathrm{ab}}$ & $0.25(0.01)^{\mathrm{bcd}}$ & $17.48(0.17)^{\mathrm{b}}$ & $0.24(0.004)^{\mathrm{b}}$ \\
\hline & 96 & $18.06(1.92)^{\mathrm{bc}}$ & $0.26(0.02)^{\mathrm{bcd}}$ & $16.85(0.20)^{b}$ & $0.25(0.008)^{\mathrm{b}}$ \\
\hline \multirow[t]{2}{*}{ Water } & 48 & $17.33(1.85)^{\mathrm{bc}}$ & $0.18(0.02)^{\mathrm{d}}$ & $17.24(1.08)^{\mathrm{b}}$ & $0.21(0.013)^{\mathrm{b}}$ \\
\hline & 96 & $10.75(1.57)^{d}$ & $0.20(0.01)^{\mathrm{cd}}$ & $14.15(1.11)^{\mathrm{b}}$ & $0.21(0.014)^{\mathrm{b}}$ \\
\hline \multirow[t]{2}{*}{ X. axonopodis } & 48 & $14.43(2.54)^{\mathrm{cd}}$ & $0.22(0.01)^{\mathrm{bcd}}$ & $30.71(2.11)^{\mathrm{a}}$ & $0.21(0.014)^{\mathrm{b}}$ \\
\hline & 96 & $13.13(1.64)^{\mathrm{d}}$ & $0.18(0.01)^{\mathrm{d}}$ & $33.28(1.92)^{\mathrm{a}}$ & $0.22(0.010)^{\mathrm{b}}$ \\
\hline \multirow[t]{2}{*}{ R. solanacearum } & 48 & $17.33(1.73)^{\mathrm{bc}}$ & $0.30(0.03)^{\mathrm{ab}}$ & $19.04(0.89)^{\mathrm{b}}$ & $0.19(0.017)^{\mathrm{bc}}$ \\
\hline & 96 & $22.75(1.77)^{\mathrm{a}}$ & $0.37(0.02)^{\mathrm{a}}$ & $34.61(2.77)^{\mathrm{a}}$ & $0.27(0.027)^{\mathrm{b}}$ \\
\hline \multirow[t]{2}{*}{ E. carotovora } & 48 & $21.48(1.28)^{\mathrm{ab}}$ & $0.30(0.02)^{\mathrm{ab}}$ & $18.65(1.03)^{\mathrm{b}}$ & $0.37(0.019)^{\mathrm{a}}$ \\
\hline & 96 & $22.36(3.67)^{\mathrm{a}}$ & $0.25(0.04)^{\mathrm{bcd}}$ & $18.63(1.83)^{\mathrm{b}}$ & $0.19(0.023)^{\mathrm{bc}}$ \\
\hline
\end{tabular}

Different letters in columns indicate significant differences (ANOVA, Tukey $\mathrm{p} \leq 0.05$ ). Numbers in parenthesis represent standard errors of the means. Independent experiments were repeated three times $(n=36)$. 
Therefore, the highest levels of phenolic compounds and flavonoids were found with multiple inoculation treatments, whereas the highest PPO enzymatic activity was seen in the experiments consisting of a single inoculation (Table IV).

\section{DISCUSSION}

Tubers infiltrated with suspensions of $E$. carotovora showed visible disease symptoms. According to Romeiro (2005), these bacteria produce pectinases that degrade pectin, affecting organs such as tubers, bulbs, and fruits. The absence of disease symptoms and the occurrence of a hypersensitive response (HR) in tubers inoculated with $R$. solanacearum indicated the resistance of the Agata cultivar to this bacterial isolate. This pathogen exhibits great genetic variation, and most of the isolates easily lose pathogenicity during culturing in growth medium (Kelman and Sequeira, 1965). In this case, the defense responses observed in the Agata cultivar may be related to growth conditions of the pathogen as well as to the presence of noncapsuled isolates (Sequeira and Graham, 1977).

Observation of tubers inoculated with suspensions of $X$. axonopodis confirmed that the potato is a non-host plant. Similarly, control treatments (inoculated with water) did not induce any defense signals.

Single and multiple inoculations of leaves with bacterial suspensions of $X$. axonopodis and $R$. solanacearum led to a $\mathrm{HR}$ at $24 \mathrm{hpi}$, and leaves inoculated with $E$. carotovora showed disease symptoms. The $\mathrm{HR}$ is characterized by necrosis at the site of the infection (González et al., 2006) and impaired growth of the pathogens (Greenberg, 1997). The HR indicates interactions where there is incompatibility
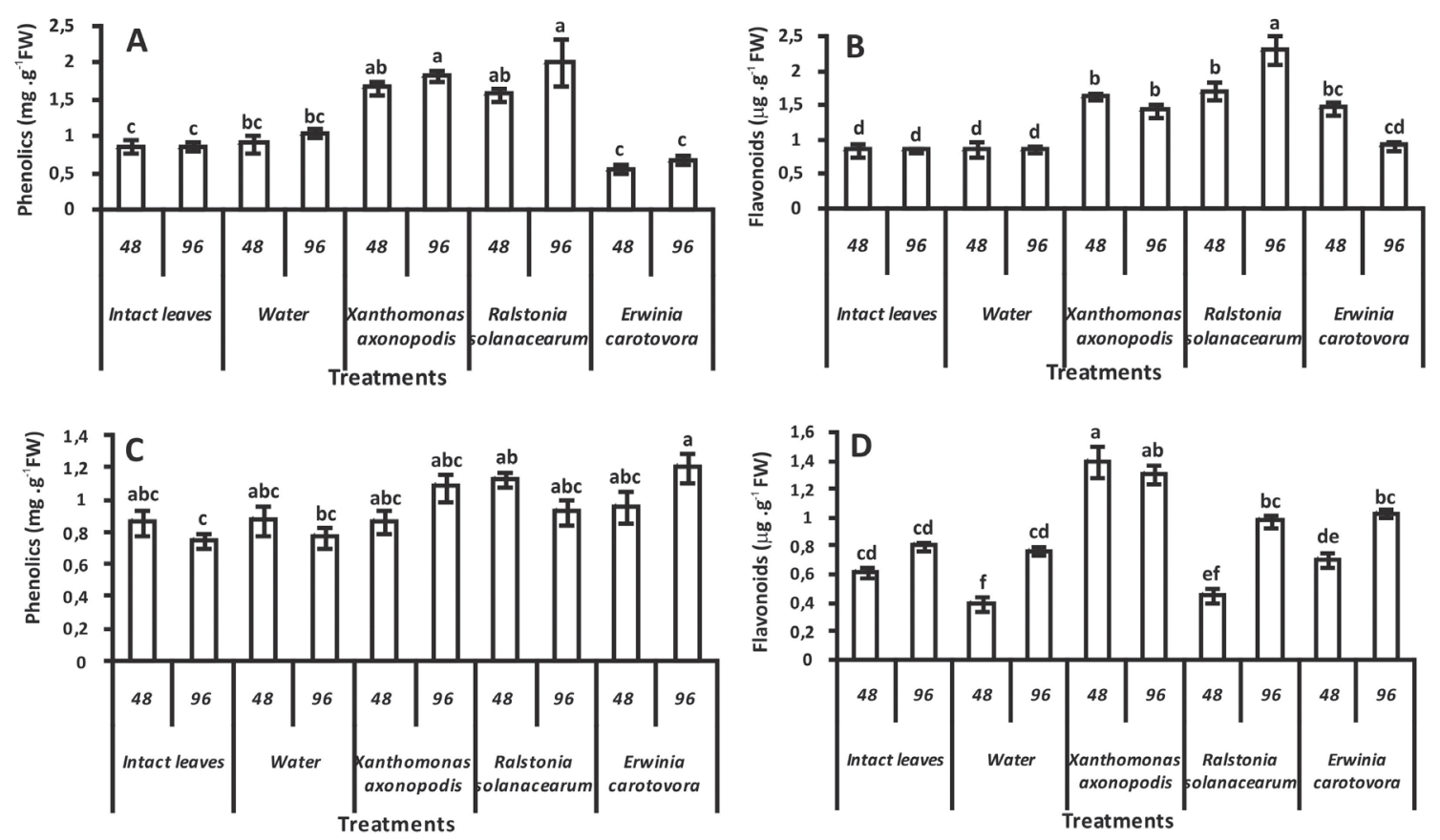

Figure 1: Contents of phenolic compounds (A, C) and flavonoids (B, D) in leaves of Solanum tuberosum analyzed after multiple (A-B) and single (C-D) inoculations with bacterial suspensions (48 and $96 \mathrm{hpi}$ - hours post-inoculation). The different letters indicate means significant differences (ANOVA, Tukey $\mathrm{p} \leq 0.05$ ). Bars represent standard errors. Independent experiments were repeated three times $(n=36)$. 


\section{TABLE II}

Polyphenol oxidase and peroxidase activities, phenolic compounds and flavonoids levels in leaves of Solanum tuberosum analyzed after multiple inoculations and determined at different leaf ages (location). Means were grouped independently of time (48 or 96 hpi hours post-inoculation).

\begin{tabular}{|c|c|c|c|c|c|}
\hline Leaf location & Treatments & $\begin{array}{c}\text { PPO } \\
\left(\Delta A b s . m i n^{-1} . \mu g^{-1} \text { protein }\right)\end{array}$ & $\begin{array}{c}\mathrm{POX} \\
\text { (mkatal } \mu g^{-1} \text { protein) }\end{array}$ & $\begin{array}{c}\text { Phenolics } \\
\left(m g \cdot g^{-1} F W\right)\end{array}$ & $\begin{array}{l}\text { Flavonoids } \\
\left(\mu g \cdot g^{-1} F W\right)\end{array}$ \\
\hline \multirow[t]{5}{*}{ Basal } & Intact leaves & $28.42(2.31)^{\mathrm{ab}}$ & $0.31(0.02)^{\mathrm{abcd}}$ & $0.62(0.04)^{\mathrm{f}}$ & $0.67(0.08)^{\mathrm{e}}$ \\
\hline & Water & $19.30(2.24)^{\mathrm{bcde}}$ & $0.24(0.03)^{\mathrm{cde}}$ & $1.0(0.15)^{\mathrm{bcde}}$ & $0.79(0.13)^{\mathrm{e}}$ \\
\hline & $X$. axonopodis & $20.91(1.62)^{\mathrm{abcde}}$ & $0.20(0.03)^{\mathrm{de}}$ & $1.6(0.04)^{\mathrm{bcd}}$ & $1.58(0.04)^{\mathrm{abcd}}$ \\
\hline & R. solanacearum & $25.75(1.52)^{\mathrm{abc}}$ & $0.39(0.03)^{\mathrm{a}}$ & $1.51(0.02)^{\mathrm{bcd}}$ & $1.81(0.22)^{\mathrm{abc}}$ \\
\hline & E. carotovora & $29.47(2.46)^{\mathrm{a}}$ & $0.35(0.04)^{\mathrm{ab}}$ & $0.54(0.03)^{\mathrm{f}}$ & $1.14(0.06)^{\mathrm{cde}}$ \\
\hline \multirow[t]{5}{*}{ Intermediate } & Intact leaves & $17.16(0.31)^{\text {cdef }}$ & $0.25(0.01)^{\mathrm{bcde}}$ & $0.8(0.10)^{\mathrm{ef}}$ & $0.79(0.09)^{\mathrm{e}}$ \\
\hline & Water & $13.58(2.12)^{\mathrm{efgh}}$ & $0.18(0.01)^{\mathrm{de}}$ & $0.94(0.06)^{\mathrm{de}}$ & $0.77(0.08)^{\mathrm{e}}$ \\
\hline & $X$. axonopodis & $13.34(0.64)^{\mathrm{efgh}}$ & $0.20(0.02)^{\mathrm{de}}$ & $1.67(0.14)^{\mathrm{abc}}$ & $1.69(0.03)^{\mathrm{abc}}$ \\
\hline & R. solanacearum & $18.30(1.96)^{\mathrm{cdef}}$ & $0.35(0.02)^{\mathrm{ab}}$ & $1.7(0.28)^{\mathrm{ab}}$ & $1.97(0.24)^{\mathrm{ab}}$ \\
\hline & E. carotovora & $22.87(0.63)^{\mathrm{abcd}}$ & $0.29(0.03)^{\mathrm{abcd}}$ & $0.62(0.09)^{\mathrm{f}}$ & $1.04(0.12)^{\mathrm{de}}$ \\
\hline \multirow[t]{5}{*}{ Apical } & Intact leaves & $10.89(1.46)^{\mathrm{fgh}}$ & $0.21(0.01)^{\mathrm{de}}$ & $0.97(0.08)^{\mathrm{cde}}$ & $0.96(0.06)^{\mathrm{de}}$ \\
\hline & Water & $9.25(0.99)^{\mathrm{gh}}$ & $0.15(0.01)^{\mathrm{e}}$ & $1.3(0.10)^{\mathrm{bcde}}$ & $0.99(0.06)^{\mathrm{de}}$ \\
\hline & $X$. axonopodis & $7.09(0.35)^{\mathrm{h}}$ & $0.19(0.02)^{\mathrm{de}}$ & $1.9(0.08)^{\mathrm{a}}$ & $1.51(0.14)^{\mathrm{abcd}}$ \\
\hline & R. solanacearum & $16.08(1.66)^{\mathrm{defg}}$ & $0.26(0.03)^{\mathrm{abcde}}$ & $2.11(0.34)^{\mathrm{a}}$ & $2.22(0.24)^{\mathrm{a}}$ \\
\hline & E. carotovora & $13.42(1.99)^{\mathrm{efgh}}$ & $0.19(0.02)^{\mathrm{de}}$ & $0.65(0.09)^{\mathrm{f}}$ & $1.44(0.18)^{\mathrm{bcd}}$ \\
\hline
\end{tabular}

Different letters in columns indicate significant differences (ANOVA, Tukey $\mathrm{p} \leq 0.05$ ). Numbers in parenthesis represent standard errors of the means. Independent experiments were repeated three times $(n=12$, for each leaf location).

\section{TABLE III}

Phenolic compounds, flavonoids, protein and chlorophyll levels and polyphenol oxidase (PPO) and peroxidase (POX) activity in untreated leaves (intact leaves) of Solanum tuberosum evaluated at different leaf ages. Means were grouped independently of the period post-inoculation (48 or $96 \mathrm{hpi}$ ).

\begin{tabular}{|c|c|c|c|c|c|c|}
\hline Leaf location & $\begin{array}{c}\text { PPO } \\
\left(\triangle A b s . m^{-1}{ }^{-1}\right. \\
\mu g^{-1} \text { protein) }\end{array}$ & $\begin{array}{c}\mathrm{POX} \\
\text { (mkatal. } \mu g^{-1} \\
\text { protein) }\end{array}$ & $\begin{array}{c}\text { Phenolic } \\
\text { compounds } \\
\left(m g \cdot g^{-1} F W\right)\end{array}$ & $\begin{array}{l}\text { Flavonoids } \\
\left(\mu g \cdot g^{-1} F W\right)\end{array}$ & $\begin{array}{c}\text { Protein } \\
\left(m g \cdot g^{-1} F W\right)\end{array}$ & $\begin{array}{l}\text { Chlorophyll } \\
\left(m g \cdot g^{-1} F W\right)\end{array}$ \\
\hline Basal & $28.42(2.31)^{\mathrm{a}}$ & $0.31(0.02)^{\mathrm{a}}$ & $0.62(0.04)^{\mathrm{b}}$ & $0.67(0.08)^{\mathrm{b}}$ & $1.80(0.10)^{\mathrm{c}}$ & $11.72(0.64)^{\mathrm{c}}$ \\
\hline Intermediate & $17.16(0.31)^{\mathrm{b}}$ & $0.25(0.01)^{b}$ & $0.80(0.10)^{\mathrm{ab}}$ & $0.79(0.09)^{\mathrm{ab}}$ & $2.32(0.01)^{\mathrm{b}}$ & $16.01(0.99)^{\mathrm{b}}$ \\
\hline Apical & $10.89(1.46)^{\mathrm{c}}$ & $0.21(0.01)^{\mathrm{c}}$ & $0.97(0.08)^{\mathrm{a}}$ & $0.97(0.06)^{\mathrm{a}}$ & $2.87(0.14)^{\mathrm{a}}$ & $19.43(0.16)^{\mathrm{a}}$ \\
\hline
\end{tabular}

Different letters in columns indicate significant differences (ANOVA, Tukey $\mathrm{p} \leq 0.05$ ). Numbers in parenthesis represent standard errors of the means. Independent experiments were repeated three times $(n=12$, for each leaf location). 
Polyphenol oxidase (PPO), peroxidase (POX), phenolic compounds and flavonoids in leaves of Solanum tuberosum analyzed after multiple and single inoculations, independently of the bacterial treatment.

\begin{tabular}{|c|c|c|c|c|c|}
\hline Treatments & hpi & $\begin{array}{c}\operatorname{PPO}\left(\Delta A b s . \mathrm{min}^{-1}\right. \\
\left.. \mu g^{-1} \text { protein }\right)\end{array}$ & $\begin{array}{l}\mathrm{POX}(\text { mkatal } \\
\left.\mu g^{-1} \text { protein }\right)\end{array}$ & $\begin{array}{l}\text { Phenolic compounds } \\
\quad\left(m g \cdot g^{-1} F W\right)\end{array}$ & $\begin{array}{l}\text { Flavonoids } \\
\left(\mu g \cdot g^{-1} F W\right)\end{array}$ \\
\hline \multirow[t]{2}{*}{ Intact leaves } & 48 & $17.48(0.17)^{\mathrm{b}}$ & $0.24(0.004)^{\mathrm{a}}$ & $0.86(0.08)^{\mathrm{b}}$ & $0.78(0.075)^{\mathrm{b}}$ \\
\hline & 96 & $16.85(0.20)^{\mathrm{b}}$ & $0.25(0.008)^{\mathrm{a}}$ & $0.75(0.05)^{\mathrm{b}}$ & $0.80(0.033)^{\mathrm{b}}$ \\
\hline \multirow[t]{2}{*}{ Single } & 48 & $22.62(1.43)^{\mathrm{ab}}$ & $0.25(0.018)^{\mathrm{a}}$ & $0.99(0.05)^{\mathrm{ab}}$ & $0.83(0.089)^{\mathrm{b}}$ \\
\hline & 96 & $29.23(2.05)^{\mathrm{a}}$ & $0.22(0.013)^{\mathrm{a}}$ & $1.07(0.05)^{\mathrm{ab}}$ & $1.10(0.041)^{\mathrm{b}}$ \\
\hline \multirow[t]{2}{*}{ Intact leaves } & 48 & $19.59(3.53)^{b}$ & $0.25(0.011)^{\mathrm{a}}$ & $0.87(0.18)^{b}$ & $0.85(0.179)^{\mathrm{b}}$ \\
\hline & 96 & $18.06(1.92)^{\mathrm{b}}$ & $0.26(0.020)^{\mathrm{a}}$ & $0.74(0.12)^{\mathrm{b}}$ & $0.84(0.078)^{\mathrm{b}}$ \\
\hline \multirow[t]{2}{*}{ Multiple } & 48 & $16.70(1.68)^{b}$ & $0.27(0.028)^{\mathrm{a}}$ & $1.20(0.20)^{\mathrm{ab}}$ & $1.54(0.075)^{\mathrm{a}}$ \\
\hline & 96 & $19.64(1.53)^{b}$ & $0.28(0.032)^{\mathrm{a}}$ & $1.49(0.25)^{\mathrm{a}}$ & $1.59(0.250)^{\mathrm{a}}$ \\
\hline
\end{tabular}

Different letters in columns indicate significant differences (ANOVA, Tukey $\mathrm{p} \leq 0.05$ ). Numbers in parenthesis represent standard errors of the means. Independent experiments were repeated three $(n=36)$ and nine $(n=36)$ times on multiple and single inoculations, respectively. Hours post-inoculation (hpi).

between the pathogen and the host plant (Romeiro, 2001). The HR observed in the leaves of the Agata cultivar was accompanied by biochemical defense responses, depending on the type of inoculation (single or multiple), as well as the species of pathogen. Biochemical changes in the cells surrounding necrotic lesions resulted in de novo synthesis of compounds, such as phytoalexins (Nicholson and Hammerschmidt, 1992). Moreover, the accumulation of phenolic compounds and their oxidation by increased PPO and POX activity are also related to plant defense (Agrios, 1997; De Ascensão and Dubery, 2003; González et al., 2006).

Independently of the leaf age, PPO activity in multiple inoculations was characterized by significant differences among the treatments evaluated. There was a significant increase in PPO activity in leaves inoculated with $R$. solanacearum and $E$. carotovora, while a similar increase in POX activity resulted from the infection with $R$. solanacearum (Table I).

Considering only leaf age, the untreated apical leaves (the youngest) showed significantly higher levels of total phenolic compounds and flavonoids, and lower levels of PPO and POX activity, compared to the basal leaves (Table III). It is understood that phenolic concentration depends on the stage of leaf development (Lavola et al., 1998), and the high amounts of phenolic compounds found in young leaves often decrease with leaf maturation (Manetas, 2006).

Multiple inoculations with the incompatible bacteria $R$. solanacearum and $X$. axonopodis resulted in increased levels of phenolic compounds in all leaves analyzed. Significantly higher levels of phenolics were observed in apical leaves compared to intermediate and basal leaves (Table III). Flavonoid contents also increased in the apical leaves after multiple inoculations with $R$. solanacearum (Table II). After multiple infections, flavonoid levels were higher than the constitutive levels found in the intact apical leaves (Table II). These results indicated that these incompatible bacteria may play a role as inducers of the defense metabolism in the Agata cultivar. Therefore, these strains could be used to enhance the defense responses in the potato, minimizing the effects of a possible later infection by compatible bacteria. 
Untreated basal leaves showed the highest constitutive levels of PPO activity, compared to intermediate and apical leaves (Table III). After multiple inoculations, the highest PPO activities were found in basal leaves of plants inoculated with $E$. carotovora (Table II). However, the increase in this enzyme activity was not sufficient to avoid the development of the disease in basal leaves of the infected plants. It has been reported that PPO clearly plays a role in the resistance of tomato to $P$. syringae (Thipyapong et al., 2004). Likewise, leaves of chickpea (Cicer arietinum L.) showed increased PPO activity after inoculation with Ascochyta rabei (Khirbat and Jalali, 1998), implying that this enzyme may be involved in the hypersensitive response. It has also been reported that PPO expression promotes programmed cell death, likely generating an environment that would discourage adventitious colonization by pathogens (Thipyapong et al., 1997).

Untreated basal leaves of the Agata cultivar showed higher levels of POX activity than did the intermediate and apical leaves (Table III). After multiple inoculations, potato leaves inoculated with $R$. solanacearum showed an increase in POX activity. Interestingly, the greatest increase in POX activity occurred in basal leaves after $R$. solanacearum inoculations (Table II). The observed resistance in relation to leaf age, where the older (basal) leaves were more resistant, appears to be related to POX activity (Kortekamp and Zyprian, 2003). The highest POX activity in older leaves does not occur passively over time, but is instead regulated differently by the plant in old and young leaves (Barto and Cipollini, 2005). During leaf expansion of A. thaliana, as well as in the senescent tissues, an increase in the total peroxidase activity was reported, and a peak of activity was detected at the end of the leaf expansion (Abarca et al., 2001). Kortekamp and Zyprian (2003) observed either a higher basal level or a rapid enhancement of peroxidase activity in grapevines resistant to the fungus Plasmopara viticola. In cucumbers, lignification mediated by POX activity was one of the most important defense responses (Nicholson and Hammerschmidt, 1992). POX catalyzes the cell-wall crosslinking, promoting the strengthening of cell walls, and therefore acting against the pathogen attack (Agrios, 1997; Crozier et al., 2000; De Ascensão and Dubery, 2003).

Untreated basal leaves showed lower levels of soluble proteins and chlorophyll content than did apical leaves (Table III). Low levels of proteins and chlorophyll in the leaves indicate a process of senescence. During senescence, leaf cells undergo drastic metabolic degeneration of cellular structures, starting with chlorophyll catabolism as well as protein and RNA degradation, with the loss of photosynthetic activity (Hörtensteiner and Feller, 2002). The senescence process has also been associated with an increase in oxidative stress, as revealed by hydrogen peroxide accumulation, lipid peroxidation, and cell wall stiffening (Cabello et al., 2006). Moreover, plant peroxidases create a highly toxic environment by massively producing reactive oxygen species (oxidative burst), which results in adverse growth conditions for microorganisms (Dellanoy et al., 2004; Passardi et al., 2005).

Single inoculations in intermediate leaves resulted in a significant increase in PPO activity when leaves were inoculated with $R$. solanacearum and $X$. axonopodis, suggesting that PPO may be a plant defense response against incompatible bacteria. A significant increase in POX activity occurred when intermediate leaves were inoculated with E. carotovora (Table I). However, the increase in POX activity failed to prevent the development of the disease.

The highest PPO activity was observed in the single inoculation, whereas there was no significant difference in POX activity during the two inoculation experiments (Table IV). Our results suggest that the defense responses, which vary in accordance with the type of treatment, may be related to systemic acquired resistance mechanisms. A strong increase in the PPO activity during the experiments with intermediate leaves may also indicate a previous increase in the levels of phenolc 
compounds, which are substrates to form compounds that are toxic to microorganisms. On the other hand, the delay in the increase of this enzyme activity observed in the experiment with multiple inoculations may be a consequence of high stress caused by the infection of the majority of the plant leaves. The resistance depends on the cell autonomy and the timing and intensity of defense responses (Moraes, 1998). Thus, when these responses occur in a rapid and coordinated manner (Yamamizo et al., 2006), they result in resistance against pathogens. Resistance or susceptibility in the potato cv. Agata resulted in defense responses that differed qualitatively and quantitatively, depending on leaf age, type of inoculation performed (single or multiple), and on the interaction between the plant and the pathogen.

\section{ACKNOWLEDGEMENTS}

The authors are grateful to Dr. Jarbas Rodrigues de Oliveira, Dr. Valmir Duarte and Dr. Sérgio F. Pascholati for methodological assistance. We also thank CAPES for the fellowship.

\section{REFERENCES}

ABARCA D, MARTIN, M, SABATER B (2001) Differential leaf stress responses in young and senescent plants. Plant Physiol, 113: 409-415

ABBASI PA, GRAHAM TL (2001) Age-related regulation of induced isoflavonoid responses in soybean lines differing in inherent elicitation competency. Physiol Mol Plant Pathol, 59: 143-152

AGRIOS GN (1997) Plant Pathol, $4^{\text {th }}$ ed. San Diego: Academic Press, pp: 93-114

ANWAR MN, MAJUMDER SK, SHETTY HS (1995) Changes in phenolic acids in sorghum and maize leaves infected with Peronoclespora sorghi. Indian Phytopathol, 48: 21-26

ARNALDOS TL, MUÑOZA R, FERRER MA, CALDERÓN AA (2001) Changes in phenol content during strawberry (Fragaria ananassa, cv. Chandler) callus culture. Physiol Plantarum, 113: 315-322

BARTO EK, CIPOLLINI D (2005) Testing the optimal defense theory and the growth-differentiation balance hypothesis in Arabidopsis thaliana. Oecol, 146: 169178

BERDNAREK P, SCHNEIDER B, SVATOS A, OLDHAM NJ, HAHLBROCK K (2005) Structural complexity, differential response to infection, and tissue specificity of indolic and phenylpropanoid secondary metabolism in Arabidopsis roots. Plant Physiol, 138: 1058-1070
BRADFORD MM (1976) A rapid and sensitive method for the quantitation of microgram quantities of protein utilizing the principle of protein-dye binding. Anal Biochem, 72: 248-254

CABELlO P, AGÜERA E, DE LA HABA P (2006) Metabolics changes during natural ageing in sunflower (Helianthus annus) leaves: expression and activity of glutamine synthetase isoforms are regulated differently during senescence. Physiol Plantarum, 128: 175-185

CROZIER A, KAMIYA Y, BISHOP G, YOKOTA T (2000) Biosynthesis of Hormones and Elicitor Molecules. In: BUCHANAN BB, GRUISSEM W, JONES RL (eds) Biochemistry and Molecular Biology of Plants. Maryland: Library of Congress Catalogingin-Publication Data, Rockville, pp: 850-928

DE ASCENSÃO ARFDC, DUBERY IA (2003) Soluble and wall-bound phenolics and phenolic polymers in Musa acuminate roots exposed to elicitors from Fusarium oxysporum f. sp. cubense. Phytochem, 63: 679-686

DELLANOY E, MARMEY P, PENEL C, NICOLE M (2004) Les peroxidases végétales de classe III. Acta Bot Gall, 353-380

DIXON RA, ACHNINE L, KOTA P, LIU CJ, REDDY MSS, WANG L (2002) The phenylpropanoid pathway and plant defence-a genomics perspective. Mol Plant Pathol, 3: 371-390

DIXON RA, PAIVA NL (1995) Stress-induced phenylpropanoid metabolism. The Plant Cell, 7: 10851087

EHRENFELD N, CAÑóN P, STANGE C, MEDINA C, ARCE-JOHNSON P (2005) Tobamovirus coat protein $\mathrm{CPCg}$ induces an HR-like response in sensitive tobacco plants. Mol and Cells, 19: 418-427

FIELD B, JORDAN F, OSBOURN A (2006) First encounters-deployment of defence-related natural products by plants. The New Phytol, 172: 193-207

GANDIA-HERRERO F, JIMÉNEZ-ATIÉNZAR M CABANES J, GARCIA-CARMONA F, ESCRIBANO J (2005) Differential activation of a latent polyphenol oxidase mediated by sodium dodecyl sulfate. J Agric Food Chem, 53: 6825-6830

GONZÁLEZ EM, DE ANCOS B, CANO MP (1999) Partial characterization of polyphenol oxidase activity in raspberry fruits. J Agric Food Chem, 47: 4068-4072

GONZÁLEZ J, REYES F, SALAS C, SANTIAGO M, CODRIANSKY Y, COLIHEUQUE N, SILVA H (2006) Arabidopsis thaliana: A model host plant to study plant-pathogen interaction using chilean field isolates of Botrytis cinerea. Biol Res, 39: 221-228

GREENBERG JT (1997) Programmed cell death in plantpathogen interactions. Annu Rev Plant Physiol Plant Mol Biol, 48: 525-545

HARBORNE JB (1999) The comparative biochemistry of phytoalexin induction in plants. Biochem System Ecol, 27: $335-367$

HÖRTENSTEIN S, FELLER U (2002) Nitrogen metabolism and remobilization during senescence. J Experim Bot, 53: 927-937

JUSKIEWICZ J, ZDUNCZYK Z, FORNAL J (2005) Nutritional properties of tubers of conventionally bred and transgenic lines of potato resistant to necrotic strain of Potato virus $Y\left(\mathrm{PVY}^{\mathrm{N}}\right)$. Acta Biochem Polonia, 52: 725-729

JWA NS, AGRAWAL GK, TAMOGAMI S, YONEKURA M, HAN O, IWAHASHI H, RAKWAL R (2006) Role of defense/stress-related marker genes, proteins and secondary metabolites in defining rice self-defense mechanisms. Plant Physiol Biochem, 44: 261-273

KELMAN A, SEQUEIRA L (1965) Root-to-root spread of Pseudomonas solanacearum. Phytopathol, 55: 304-309 
KHIRBAT SK, JALALI BL (1998) Polyphenol oxidase and bound phenol content in leaves of chickpea (Cicer arietinum L.) after inoculation with Ascochyta rabei. Legume Res, 21: 198-200

KORTEKAMP A, ZYPRIAN E (2003) Characterization of Plasmopara-resistance in grapevine using in vitro plants. J Plant Physiol, 160: 1393-1400

LAVOLA A, JULKUNEN-TIITTO R, ROININEN H, APHALO P (1998) Host-plant preference of an insect herbivore mediated by $\mathrm{UV}-\mathrm{B}$ and $\mathrm{CO}_{2}$ in relation to plant secondary metabolites. Biochem System Ecol, 26: 1-12

LEWIS CE, WALKER JRL, LANCASTER JE, SUTTON KH (1998) Determination of anthocynins, flavonoids and phenolic acids in potatoes. I: Coloured cultivars of Solanum tuberosum L. J Sci Food Agric, 77: 45-57

LI L, STEFFENS JC (2002) Overexpression of polyphenol oxidase in transgenic tomato plants results in enhanced bacterial disease resistance. Planta, 215: 239-247

LORENC-KUKULA K, JAFRA S, OSZMIÁNSKI I, SZOPA J (2005) Ectopic Expression of Anthocyanin 5$O$-Glucosyltransferase in Potato Tubers Causes Increased Resistance to Bacteria. J Agric Food Chem, 53: $272-281$

MANETAS Y (2006) Why some leaves are anthocyanic and why most anthocyanic leaves are red? Flora, 201: 163-177

MORAES MG (1998) Mecanismos de resistência sistêmica adquirida em plantas. Rev Annu Pat Veg, 6: 261-284

NASARENO NRX, JACCOUD FILHO DS (2003) Doenças fúngicas. In: PEREIRA AS, DANIELS J (eds) O cultivo da batata na região sul do Brasil. Brasília: Embrapa Inf Tecnol, pp: 239-276

NICHOLSON RL, HAMMERSCHMIDT R (1992) Phenolic compounds and their role in disease resistance. Annu Rev Phytopathol, 30: 369-389

OLIVEIRA AMR, SILVEIRA JRP, DUARTE V (2003) Doenças bacterianas. In: PEREIRA AS, DANIELS J (eds) O cultivo da batata na região sul do Brasil. Brasília: Embrapa Inf Tecnol, pp: 277-299

ORTEGA X, VELÁSQUEZ JC, PÉREZ LM (2005) IP3 production in the hypersensitive response of lemon seedlings against Alternaria alternata involves active protein tyrosine kinases but not a G-protein. Biol Res 38: 89-99

PASSARDI F, COSIO C, PENEL C, DUNAND C (2005) Peroxidases have more functions than a Swiss army Knife. Plant Cell Rep, 24: 255-265

PINELI LLO, MORETTI CL, ALMEIDA GC, SANTOS
JZ, ONUKI ACA, NASCIMENTO, ABG (2006) Caracterização química e física de batatas Ágata e Monalisa minimamente processadas. Ciênc Tecnol Aliment, 26: 127-134

RANDHIR R, SHETTY P, SHETTY K (2002) L- Doppa and total phenolic stimulation in dark germinated fava bean in response to peptide and phytochemical elicitors. Process Biochem, 37: 1247-1256

RAUSCHER GM, SMART CD, SIMKO I, BONIERBALE M, MAYTON H, GREENLAND A, FRY WE (2006) Characterization and Mapping of $R_{P i-b e r}$, a Novel Potato Late Blight Resistance Gene from Solanum berthaultii. Theor Appl Genet, 112: 674-687

ROMEIRO RS (2001) Métodos em Bacteriologia de Plantas. Viçosa MG Brasil: Editora UFV: Universidade Federal de Viçosa, pp: 55-64

ROMEIRO RS (2005) Bactérias Fitopatogênicas. Viçosa MG Brasil: Editora UFV: Universidade Federal de Viçosa, pp: 183-210

SEQUEIRA L, GRAHAM TL (1977) Agglutination of avirulent strains of Pseudomonas solanacearum by the potato lectin. Physiol Plant Pathol, 11: 43-53

THIPYAPONG P, JOEL DM, STEFFENS JC (1997) Differential expression and turnover of the tomato polyphenol oxidase gene family during vegetative and reproductive development. Plant Physiol, 113: 707-718

THIPYAPONG P, STEFFENS JC (1997) Tomato polyphenol oxidase: Differential response of the polyphenol oxidase $\mathrm{F}$ promoter to injuries and wound signals. Plant Physiol, 115: 409-418

THIPYAPONG P, HUNT MD, STEFFENS JC (2004) Antisense downregulation of polyphenol oxidase results in enhanced disease susceptibility. Planta, 220: 105-117

TOOR, RK, SAVAGE, GP (2005) Antioxidante activity in different fractions of tomato. Food Research International, 38: 487-494

WHITHAM FH, BLAYDES DF, DEVLIN RM (1971) Experiments in Plant Physilogy. $1^{\text {st }}$ ed. New York: D. van Nostrand Company, pp. 55-58

YAMAMIZO C, KUCHIMURA K, KOBAYASHI A, KATOU S, KAWAKITA K, JONES JDG, DOKE N, YOSHIOKA H (2006) Rewiring mitogen-activated protein kinase cascade by positive feed-back confers potato blight resistance. Plant Physiol, 140: 681-692

YAMAMOTO $M$, NAKATSURA $S$, OTANI $H$, KOHMOTO K, NISHIMURA S (2000) (+)- Catechin acts as an infection-inhibiting factor in strawberry leaf. Phytopathol, 90: 595-600 
